\title{
EFEKTIVITAS SUPLEMENTASI Fe+ ASAM FOLAT TERHADAP KENAIKAN KADAR Hb PADA IBU HAMIL YANG TERINFEKSI MALARIA DI KABUPATEN NABIRE
}

\author{
Mulyanti, Muhammad Sulchan \\ Program Studi Ilmu Gizi Fakultas Kedokteran Universitas Diponegoro \\ Jl.Dr.Sutomo No.18, Semarang, Telp (024) 8453708, Email : gizifk@ undip.ac.id
}

\begin{abstract}
Background: In 2010, Indonesia became one of the four countries in Asia with a fairly high prevalence of anemia. In addition to the prevalence of malaria in pregnancy and childbirth by $18 \%$, of which $60 \%$ are caused by Plasmodium falcifarum, $32 \%$ by Plasmodium vivax, $4.5 \%$ for mixed infections. Plasmodium parasite infection in pregnant women can lead to anemia sufferer through direct mechanisms pengambatan erythropoiesis and erythrocyte infestation, and the mechanism of the side effects of antimalarials that inhibit the provision of intake and absorption of nutrients. To prevent and treat anemia in pregnant women one of which Fe Folic Acid supplementation program.

Methods: This study was conducted in order to determine the change of Hb in pregnant women were infected with malaria who received $\mathrm{Fe}^{2+}$ Folic Acid supplementation. Descriptive analytic study with case-control approach, a sample of 126 people taken by consecutive and matching and samples were divided into two groups: the case group and the control group.

Results: The mean change in Hb levels in the case group was $0.270 \pm 0615$ and in the control group was $0.886 \pm$ 0749 with $p<0.05$. There are significant differences in changes in both groups. Analysis of changes in Hb in group with regular supplementation $(\geq 30)$ and a group that is not routine $(<30)$ values obtained OR 3.13 and p $>0.05$.

Conclusions: In the group of cases increase Hb levels lower than the control group, so the handling of malarial anemia in pregnant women need evaluation and improvement program in order to get optimal results.
\end{abstract}

Key Words : Iron Suplementation, Malaria, Pregnancy, Hemoglobin

\begin{abstract}
ABSTRAK
Latar Belakang : Pada tahun 2010, Indonesia menjadi salah satu dari empat negara di Asia dengan prevalensi anemia yang cukup tinggi. Selain itu prevalensi malaria pada ibu hamil dan melahirkan sebesar 18\%, dimana 60\% disebabkan oleh Plasmodium falcifarum, 32\% oleh Plasmodium vivax, 4,5\% karena infeksi campuran. Infeksi parasit Plasmodium pada ibu hamil dapat menyebabkan anemia pada penderitanya melalui mekanisme langsung pengambatan eritropoesis dan infestasi eritrosit, dan mekanisme efek samping dari pemberian antimalaria yang menghambat asupan dan absorbsi zat gizi. Untuk mencegah dan mengatasi anemia pada ibu hamil salah satunya yaitu program suplementasi Fe Asam Folat.

Metode : Penelitian ini dilakukan dengan tujuan untuk mengetahui Perubahan kadar Hb pada ibu hamil trimester II dan III yang terinfeksi malaria yang mendapat suplementasi Fe Asam Folat. Penelitian bersifat deskriptif analitik dengan pendekatan case control, sampel sebanyak 126 orang yang diambil secara consecutive dan matching dan sampel dibagi dalam dua kelompok yaitu kelompok kasus dan kelompok kontrol.

Hasil : Rerata perubahan kadar Hb pada kelompok kasus sebesar $0.270 \pm 0.615$ dan pada kelompok kontrol sebesar $0.886 \pm 0.749$ dengan $p<0.05$. Ada perbedaan perubahan yang signifikan pada kedua kelompok. Analisis perubahan Hb pada kelompok dengan suplementasi rutin $(\geq 30)$ dan kelompok yang tidak rutin $(<30)$ didapatkan nilai OR 3.33 dan $p>0.05$.

Simpulan : Pada kelompok kasus kenaikkan kadar Hb lebih rendah dari kelompok kontrol, sehingga penanganan anemia pada ibu hamil malaria perlu evaluasi dan perbaikan program agar mendapatkan hasil yang optimal.

Kata Kunci : Suplementasi Fe, Malaria, Kehamilan, Hemoglobin
\end{abstract}

\section{PENDAHULUAN}

Permasalahan gizi masih menjadi masalah besar dibeberapa negara terutama di negara berkembang. Untuk merespon hal tersebut dibentuk Gerakan Scaling Up Nutrition Movement (SUN Movement). Tujuan Global SUN Movement adalah menurunkan masalah gizi, dengan fokus pada 1000 hari pertama kehidupan, yaitu fase 270 hari selama kehamilan dan 730 hari dari kelahiran sampai usia 2 tahun., ${ }^{1,30}$

Kehamilan adalah satu fase yang menjadi salah satu penentu kwalitas kesehatan anak. Pada masa kehamilan sangat rentan terhadap masalah gizi. Salah satu faktor terjadinya masalah gizi, terutama defisiensi zat gizi adalah adanya infeksi malaria. Pada tahun 2010 angka kejadian malaria yang tertinggi di Asia terjadi di empat negara yaitu 
: India, Indonesia, Pakistan dan Myanmar yaitu sebesar 29.2 juta kasus. Kabupaten Nabire dengan jumlah penduduk 129.893 jiwa adalah salah satu kabupaten di Propinsi Papua dengan prevalensi malaria yang cukup tinggi. Pada tahun 2012 terdapat 21.085 kasus yang dilaporkan yang terdiri dari 12.787 infeksi Plasmodium falcifarum, 8.289 infeksi Plasmodium vivax dan 9 kasus malaria mix. Angka ini bisa menjadi lebih besar karena tidak semua penderita malaria terjangkau oleh tempat pelayanan kesehatan dan dilaporkan. Untuk malaria pada ibu hamil, pada tahun 2012 terdapat 107 kejadian malaria yang diperoleh dari laporan 18 dari 26 Puskesmas dan Klinik kesehatan yang ada di Kabupaten Nabire. ${ }^{5,13,15,28}$

Malaria pada kehamilan berdampak negatif terhadap kesehatan ibu hamil dan janinnya. Malaria berkontribusi terhadap angka kematian ibu, bayi dan neonatal. Komplikasi malaria yang dapat ditemukan pada ibu hamil selain anemia adalah demam, hipoglikemia, malaria serebral, edema paru dan sepsis. Selain berdampak negatif terhadap kesehatan ibu malaria juga menimbulkan komplikasi terhadap janin yang dikandungnya yaitu dapat menyebabkan berat lahir rendah, abortus, kelahiran prematur, Intra Uterine Fetal Death (IUFD) / janin mati di dalam kandungan, dan Intra Uterine Growth Retardation (IUGR) / pertumbuhan janin yang terganggu. $7,17,18$

Mekanisme anemia karena plasmodium yaitu parasit menginfestasi eritrosit sehingga eritopoesis terhambat dengan mekanisme penekanan produksi eritropoetin dan gangguan retropoesis akibat produksi sitokin pada proses inflamasi. Sel darah merah yang diinfestasi oleh plasmodium akan mengalami kelainan sehingga permukaan sel menjadi tidak teratur. Sel yang mengalami kelainan segera dikeluarkan dari sirkulasi oleh limpa. Infeksi malaria pada ibu hamil juga dapat menyebabkan defisiensi glukosa-6fosfat dehidrogenase (G6DP). Obat antimalaria berkonstribusi terhadap kejadian anemia. Antimalaria seperti Quinine dan Kloroquin dapat mengakibatkan hemolisis intravascular akut, anemia berat dan gagal ginjal akut (Black-water fever). Selain itu antimalaria juga dapat merangsang $\beta$ pankreas sehingga memicu terjadinya hiperinsulinemia dan hipoglikemia. Efek lain dari terapi antimalaria adalah gangguan gastrointestinal dan saraf yang dapat bermanifestasi terhadap penghambatan asupan dan absorbsi zat gizi. Keadaan ini semakin diperparah dengan adanya gejala klinis malaria seperti menggigil, mual, dan pusing. Anemia pada ibu hamil dampak meningkatkan resiko keguguran, kejadian berat badan bayi lahir rendah (BBLR), pendarahan postpartum dan kematian perinatal. ${ }^{6,19,32}$

Sejak tahun 1970-an pemerintah melaksanakan pemberian suplemen tablet besifolat yang mengandung $200 \mathrm{mg}$ ferro sulfat setara dengan $60 \mathrm{mg}$ elemental iron dan $0,25 \mathrm{mg}$ asam folat yang diminum setiap hari berturut-turut selama minimal 90 hari $(\mathrm{Fe} 3)$ dan mulai diberikan pada saat pertama kali ibu hamil memeriksakan kehamilannya. Cakupan Fe3 di Kabupaten Nabire sebesar $21.85 \%$ masih sangat jauh dari target Renstra yaitu sebesar $88 \%$. Kementrian Kesehatan pada tahun 2010 mentapkan bahwa suplementasi $\mathrm{Fe}^{2+}$ asam folat menjadi target intervensi pada ibu hamil. ${ }^{8,13,14}$

Masalah terkait rendahnya cakupan suplementasi $\mathrm{Fe}^{+}$asam folat antara lain ketidak patuhan ibu dalam mengkonsumsi tablet $\mathrm{Fe}$ dengan alasan suplementasi fe dapat menyebabkan gangguan pada gastrointestinal seperti mual dan konstipasi. Selain itu ketidakpahaman sasaran tentang suplementasi, kesalahpahaman instruksi, distribusi suplementasi, suplementasi yang tidak tepat dosis, waktu dan interaksi dengan zat gizi lain dapat mempengaruhi keberhasilan program. Suplementasi $\mathrm{Fe}^{+}$Asam Folat didaerah endemis penyakit infeksi harus diberikan sesuai kebutuhan.. Suplementasi $\mathrm{Fe}^{+}$yang melebihi kebutuhan dapat meningkatkan resiko kelahiran prematur dan neonatal asphyxia. Beberapa negara termasuk Inggris tidak merekomendasikan suplementasi rutin untuk semua ibu hamil tanpa pemeriksaan terlebih dahulu dan tanpa monitoring. Tetapi yang juga perlu diperhatikan bahwa keadaan infeksi dapat menyebabkan anemia dan defisiensi mikronutrient lainnya, begitu juga sebaliknya. Defisiensi mikronutrien dapat meningkatkan resiko terkena infeksi. ${ }^{9}, 16,18,24,26,27,33$

Penelitian ini dilakukan dengan tujuan untuk mengetahui efektifitas suplementasi $\mathrm{Fe}^{+}$Asam Folat terhadap kenaikan Hemoglobin $(\mathrm{Hb}) \mathrm{Ibu}$ hamil yang terinfeksi malaria di Kabupaten Nabire, dengan harapan bahwa penelitian ini dapat memberikan manfaat untuk perbaikan program suplementasi $\mathrm{Fe}^{+}$asam folat pada ibu hamil didaerah endemik malaria.

\section{METODE PENELITIAN}

Penelitian ini merupakan penelitian deskriptif analitik pada lingkup gizi masyarakat dengan desain case control study untuk mempelajari hubungan suplementasi $\mathrm{Fe}^{+}$Asam 
folat dengan perubahan kadar $\mathrm{Hb}$ Ibu hamil trimester II dan III yang terinfeksi malaria di kabupaten Nabire.

Penelitian ini dilakukan di di Puskesmas yang berada diwilayah kerja Distrik Nabire yaitu Puskesmas Nabire Kota, Puskesmas Karang Mulia, Puskesmas Karang Tumaritis, Puskesmas Wonorejo, dan Puskesmas Siriwini. Data diambil pada periode 1 sampai dengan 30 mei 2013. Dengan melibatkan 10 enumerator yang mempunyai latar belakang pendidikan Diploma III kebidanan 7 orang, S1 Gizi 1 orang, Diploma III Gizi 1 orang, dan D1 Analis Kesehatan 1 orang.

Populasi dari penelitian ini adalah seluruh ibu hamil yang melakukan kunjungan Ante Natal Care (ANC) di Puskesmas tersebut. Sampel pada penelitian ini diambil secara cosecutive sampling dan Matching sebanyak 126 sampel yang dibagi dalam 2 (dua) kelompok yang dan sesuai kriteria inklusi dan eksklusi. Kriteria inklusi penelitian ini adalah ibu hamil yang bersedia melakukan pemeriksaan Kadar $\mathrm{Hb}$ minimal dua kali, pemeriksaan malaria, dan bersedia menjadi responden setelah mendapat penjelasan terkait penelitian ini yang dibuktikan dengan menandatangani lembar Informed Consent. Sedangkan kriteria eksklusinya yaitu ibu menderita infeksi serius selain malaria dan mengalami abortus dalam kehamilannya.

Pada penelitian ini yang menjadi variabel dependent adalah perubahan kadar $\mathrm{Hb}$, sedangkan variabel independent adalah suplementasi $\mathrm{Fe}^{+}$ Asam folat dan infeksi malaria. Suplementasi $\mathrm{Fe}^{+}$ Asam folat diketahui dengan metode wawancara menggunakan format kuisioner. Suplementasi $\mathrm{Fe}^{+}$ Asam folat adalah tablet $\mathrm{Fe}^{+}$asam folat yang dikonsumsi setiap bulan dan $\mathrm{Fe}^{+}$Asam folat yang diberikan adalah tablet Fe (Ferro Sulfat) yang mengandung $60 \mathrm{mg} \mathrm{Fe}^{+}$dan $0,25 \mathrm{mg}$ asam folat. Suplementasi $\mathrm{Fe}^{+}$asam folat diukur dari banyaknya tablet yang diterima untuk satu bulan pada pemeriksaan sebelumnya dikurangi jumlah yang tersisa. ${ }^{26}$

Infeksi malaria adalah keadaan dimana seorang ibu hamil dinyatakan terinfeksi parasit plasmodium setelah menjalani pemeriksaan Rapid Diagnostic Therapy (RDT). Dinyatakan dalam kategori ; negatif (bila ibu hamil tidak ditemukan plasmodium pada darahnya), $\mathrm{Pv}$ (bila teridentifikasi ada Plasmodium vivax), Pf (bila teridentifikasi ada Plasmodium falcifarum) dan $\mathrm{P}$ mix (bila teridentifikasi ada lebih dari satu jenis Plasmodium). Selain infeksi malaria data yang berkaitan dengan malaria yaitu terapi antimalaria yaitu obat antimalaria yang dikonsumsi responden yang dikategorikan : Quinine, Klorokuin dan Arthemisin Combination Therapy $(A C T){ }^{28}$

Kadar $\mathrm{Hb}$ diukur dengan metode Sahli yang dilakukan oleh Tenaga ahli laboratorium di Puskesmas tempat sampel melakukan kunjungan Ante Natal Care (ANC) . Darah yang diperiksa adalah sel darah tepi, dinyatakan dalam gr/dl. Kadar Hb1 (awal) diambil dari data sekunder yang didapat pada catatan medik responden, sedangkan $\mathrm{Hb} 2$ (akhir) diperiksa ketika data diambil. Perubahan kadar $\mathrm{Hb}$ dihitung cara mengurangi kadar $\mathrm{Hb} 2$ dengan kadar $\mathrm{Hb} 1{ }^{25}$

Data penelitian yang telah diperoleh diproses dengan editing, coding dan tabulasi. Analisis data menggunakan software spss 17 dan nutrisurvey. Normalitas data menggunakan uji Kolmogorov Smirnov. dan uji analisis data dengan uji Mann Whitney untuk mengetahui perbedaan rerata dan perubahan kadar $\mathrm{Hb}$ pada kedua kelompok, uji Wilcoxon Rank Test untuk menganalisis perbedaan kadar $\mathrm{Hb}$ pada masingmasing kelompok dan uji Pearson Chi-Square digunakan untuk uji beda variabel kategorik kedua kelompok dengan CI 95\%. ${ }^{11,21}$

\section{HASIL PENELITIAN \\ Karakteristik Responden \\ Umur Responden}

Tabel 1. Gambaran karakteristik responden berdasarkan umur

\begin{tabular}{|c|c|c|c|c|c|c|}
\hline \multirow[t]{3}{*}{ Kategori } & \multicolumn{4}{|c|}{ Kelompok } & \multirow[t]{3}{*}{ CI \% } & \multirow[t]{3}{*}{$\mathrm{P}$} \\
\hline & \multicolumn{2}{|c|}{ Mal (+) } & \multicolumn{2}{|c|}{ Mal (-) } & & \\
\hline & $\mathrm{n}$ & $\%$ & $\mathrm{n}$ & $\%$ & & \\
\hline$<20$ tahun & 9 & 14.3 & 6 & 9.5 & 95 & $0.194^{*}$ \\
\hline 20-35tahun & 53 & 84.1 & 52 & 82.5 & & \\
\hline$>35$ tahun & 1 & 1.6 & 5 & 7.9 & & \\
\hline & 63 & 100 & 63 & 10 & & \\
\hline
\end{tabular}

Keterangan : * Uji Pearson Chi-Square = tidak berbeda siknifikan 
Tabel 1 menunjukkan bahwa pada kedua kelompok penelitian persentase terbesar adalah pada kategori umur 20 tahun sampai dengan 35 tahun yaitu sebesar $53(84.1 \%)$ pada kelompok Mal (+) dan 52
(82.5\%) pada kelompok Mal (-). Hasil analisis uji beda pada kedua kelompok menunjukkan tidak ada perbedaan yang signifikan $(\mathrm{p}>0.05)$.

\section{Tingkat Pendidikan}

Tabel 2. Gambaran karkteristik responden berdasarkan tingkat pendidikan

\begin{tabular}{|c|c|c|c|c|c|c|}
\hline \multirow[t]{3}{*}{ Kategori } & \multicolumn{4}{|c|}{ Kelompok } & \multirow{3}{*}{$\begin{array}{l}\text { CI } \\
\%\end{array}$} & \multirow[t]{3}{*}{$\mathrm{P}$} \\
\hline & \multicolumn{2}{|c|}{$\operatorname{Mal}(+)$} & \multicolumn{2}{|c|}{ Mal (-) } & & \\
\hline & $\mathrm{n}$ & $\%$ & $\mathrm{n}$ & $\%$ & & \\
\hline Tidak tamat SD & 7 & 11.1 & 4 & 6.3 & 95 & $0.885^{\#}$ \\
\hline SD/MI & 7 & 11.1 & 7 & 11.1 & & \\
\hline SMP/Mts & 15 & 23.8 & 18 & 28.6 & & \\
\hline SMA/MA/SMK & 23 & 36.5 & 22 & 34.9 & & \\
\hline \multirow[t]{2}{*}{ D3/PT } & 11 & 17.5 & 12 & 19.9 & & \\
\hline & 63 & 100 & 63 & 10 & & \\
\hline
\end{tabular}

Keterangan : \# Uji Pearson Chi-Square = tidak berbeda siknifikan

Tabel 2 menunjukkan bahwa persentase terbesar responden pada kedua kelompok mempunyai latar belakang pendidikan formal setingkat SMA sebanyak $23(36.5 \%)$ responden pada kelompok $\mathrm{Mal}(+)$ dan 22 (34.95\%) responden pada kelompok
Mal(-). Hasil analisis uji beda pada kedua kelompok menunjukkan tidak ada perbedaan yang signifikan ( $\mathrm{p}>0.05)$.

\section{Jenis Pekerjaan}

Tabel 3. Gambaran karakteristik responden berdasarkan jenis pekerjaan responden

\begin{tabular}{lllllll}
\hline \multirow{2}{*}{ Kategori } & \multicolumn{4}{c}{ Kelompok } & CI \% & P \\
\cline { 2 - 5 } & \multicolumn{2}{c}{ Mal (+) } & \multicolumn{3}{c}{ Mal (-) } & \\
\cline { 2 - 5 } & $\mathrm{n}$ & $\%$ & $\mathrm{n}$ & \multicolumn{2}{c}{$\%$} & \\
\hline Ibu Rumah & 53 & 84.1 & 55 & 87.3 & & $0.661^{\#}$ \\
Tangga & 10 & 15.9 & 8 & 12.7 & & \\
PNS/TNI/Polri & & & & & & \\
\hline & 63 & 100 & 63 & 10 & & \\
\hline
\end{tabular}

Keterangan : \# Uji Pearson Chi- Square Test = tidak berbeda siknifikan

Tabel 3 menunjukkan bahwa sebagian besar responden bekerja sebagai ibu rumah tangga, yaitu sebanyak $53(84.1 \%)$ responden pada kelompok $\mathrm{Mal}(+)$ dan 55(87.3\%) responden pada kelompok
Mal(-). Hasil analisis uji beda pada kedua kelompok menunjukkan tidak ada perbedaan yang signifikan ( $p>0.05)$.

Suku Budaya

Tabel 4. Gambaran karakteristik responden berdasarkan latar belakang suku budaya

\begin{tabular}{|c|c|c|c|c|c|c|}
\hline \multirow{3}{*}{ Kategori } & \multicolumn{4}{|c|}{ Kelompok } & \multirow[t]{3}{*}{ CI $\%$} & \multirow[t]{3}{*}{$\mathrm{P}$} \\
\hline & \multicolumn{2}{|c|}{ Mal (+) } & \multicolumn{2}{|c|}{ Mal (-) } & & \\
\hline & $\mathrm{n}$ & $\%$ & $\mathrm{n}$ & $\%$ & & \\
\hline Papua Pedalaman & 20 & 31.7 & 15 & 23.8 & 95 & $0.276^{\#}$ \\
\hline Papua Pesisir & 17 & 27.0 & 13 & 20.6 & & \\
\hline \multirow[t]{2}{*}{ Non Papua } & 26 & 41.3 & 35 & 55.6 & & \\
\hline & 63 & 100 & 63 & 10 & & \\
\hline
\end{tabular}

Keterangan : \# Uji Pearson Chi-Square Test = tidak berbeda siknifikan

Berdasarkan tabel 4 diketahui bahwa persentase latar belakang suku budaya responden adalah non papua, yaitu sebesar $26(41.3 \%)$ responden pada kelompok Mal(+) dan 35 (55.6\%) responden pada kelompok Mal(-). Hasil analisis uji beda pada kedua kelompok menunjukkan tidak ada perbedaan yang signifikan $(\mathrm{p}>0.05)$.

Tingkat Pendapatan Keluarga 
Tabel 5. Gambaran karakteristik responden berdasarkan tingkat pendapatan keluarga

\begin{tabular}{ccccccc}
\hline \multirow{2}{*}{ Kategori } & \multicolumn{4}{c}{ Kelompok } & \multirow{2}{*}{ CI \% } & P \\
\cline { 2 - 4 } & \multicolumn{2}{c}{ Mal (+) } & & \\
\cline { 2 - 5 } & $\mathrm{n}$ & $\%$ & $\mathrm{n}$ & $\%$ & & \\
\hline$<\operatorname{Rp~1.710.000,00}$ & 27 & 42.9 & 31 & 49.2 & 95 & $0.475^{\#}$ \\
$\geq \operatorname{Rp~1.710.000,00~}$ & 36 & 57.1 & 32 & 50.8 & & \\
\hline & 63 & 100 & 63 & 10 & & \\
\hline
\end{tabular}

Keterangan : \# Uji Pearson Chi-Square = tidak berbeda siknifikan

Tabel 5 menunjukkan bahwa persentase terbesar responden mempunyai tingkat pendapatan diatas upah minimum regional (UMR) atau $\geq \mathrm{Rp}$ 1.710.000,00 sebanyak $36(57.1 \%)$ responden pada kelompok Mal(+) dan 32 (50.8\%) responden pada kelompok Mal(-). Hasil analisis uji beda pada kedua kelompok menunjukkan tidak ada perbedaan yang signifikan ( $\mathrm{p}>0.05)$.

\section{Tingkat Pengetahuan Gizi}

Tabel 6. Gambaran karakteristik responden berdasarkan tingkat pengetahuan gizi

\begin{tabular}{|c|c|c|c|c|c|c|}
\hline \multirow[t]{3}{*}{ Kategori } & \multicolumn{4}{|c|}{ Kelompok } & \multirow[t]{3}{*}{ CI \% } & \multirow[t]{3}{*}{$\mathrm{P}$} \\
\hline & \multicolumn{2}{|c|}{ Mal (+) } & \multicolumn{2}{|c|}{ Mal (-) } & & \\
\hline & $\mathrm{n}$ & $\%$ & $\mathrm{n}$ & $\%$ & & \\
\hline Kurang & 6 & 9.5 & 4 & 6.3 & 95 & $0.804^{\#}$ \\
\hline Cukup & 23 & 36.5 & 24 & 38.1 & & \\
\hline Baik & 34 & 54 & 35 & 55.6 & & \\
\hline & 63 & 100 & 63 & 10 & & \\
\hline
\end{tabular}

Keterangan : \# Uji Pearson Chi-Square = tidak berbeda siknifikan

Tabel 6 menunjukkan bahwa presentase terbesar tingkat pengetahuan gizi baik sebanyak $34(54 \%)$ responden pada kelompok Mal(+) dan 35(55.6\%) responden pada kelompok Mal(-). Hasil analisis uji beda pada kedua kelompok menunjukkan tidak ada perbedaan yang signifikan $(\mathrm{p}>0.05)$.

Paritas (Frekwensi Kehamilan)

Tabel 7. Gambaran karakteristik responden berdasarkan paritas

\begin{tabular}{|c|c|c|c|c|c|c|}
\hline \multirow[t]{3}{*}{ Kategori } & \multicolumn{4}{|c|}{ Kelompok } & \multirow[t]{3}{*}{ CI \% } & \multirow[t]{3}{*}{$\mathrm{P}$} \\
\hline & \multicolumn{2}{|c|}{ Mal (+) } & \multicolumn{2}{|c|}{ Mal (-) } & & \\
\hline & $\mathrm{n}$ & $\%$ & $\mathrm{n}$ & $\%$ & & \\
\hline Primigravida & 25 & 39.7 & 32 & 50.8 & 95 & $0.339^{\#}$ \\
\hline Multigravida & 37 & 58.7 & 29 & 46.0 & & \\
\hline \multirow{2}{*}{$\begin{array}{l}\text { Grandmultigravi } \\
\text { da }\end{array}$} & 1 & 1.6 & 2 & 3.2 & & \\
\hline & 63 & 100 & 63 & 10 & & \\
\hline
\end{tabular}

Keterangan : \# Uji Pearson Chi-Square = tidak berbeda siknifikan

Tabel 7 menunjukkan bahwa presentase terbesar primigravida atau kehamilan pertama yaitu pada kelompok Mal(+) dengan paritas 2 sampai sebanyak 32(50.8\%) responden. Hasil analisis uji dengan 4 kali atau kehamilan multigravida yaitu beda pada kedua kelompok menunjukkan tidak ada sebanyak 37(58.7\%) responden, sedangkan pada perbedaan yang signifikan ( $p>0.05)$.

kelompok Mal(-) adalah pada kehamilan Umur Kehamilan

Tabel 8. Gambaran karakteristik responden brdasarkan umur kehamilan

\begin{tabular}{|c|c|c|c|c|c|c|}
\hline \multirow[t]{3}{*}{ Kategori } & \multicolumn{4}{|c|}{ Kelompok } & \multirow[t]{3}{*}{ CI \% } & \multirow[t]{3}{*}{$\mathrm{P}$} \\
\hline & \multicolumn{2}{|c|}{ Mal } & \multicolumn{2}{|c|}{ Kontrol } & & \\
\hline & $n$ & $\%$ & $\mathrm{n}$ & $\%$ & & \\
\hline Trimester II & 23 & 36.5 & 29 & 46 & 95 & $0.278^{\sharp}$ \\
\hline
\end{tabular}




\begin{tabular}{lcccc}
\hline $\begin{array}{l}\text { Trimester } \\
\text { III }\end{array}$ & 40 & 63.5 & 34 & 54 \\
\hline & 63 & 100 & 63 & 10 \\
\hline
\end{tabular}

Keterangan : \# Uji Pearson Chi- Square = tidak berbeda siknifikan

Tabel 8 menunjukkan bahwa presentasi terbesar adalah pada umur kehamilan trimester III, yaitu sebanyak 40(63.5\%) responden pada kelompok Mal(+) dan 34(54\%) responden pada kelompok
Mal(-). Hasil analisis uji beda pada kedua kelompok menunjukkan tidak ada perbedaan yang signifikan ( $\mathrm{p}>0.05)$.

\section{Frekwensi Kunjungan Ante Natal Care (ANC)}

Tabel 9. Gambaran karakteristik responden berdasarkan frekwensi kunjungan ANC

\begin{tabular}{|c|c|c|c|c|c|c|}
\hline \multirow[t]{3}{*}{ Kategori } & \multicolumn{4}{|c|}{ Kelompok } & \multirow[t]{3}{*}{ CI \% } & \multirow[t]{3}{*}{$\mathrm{P}$} \\
\hline & \multicolumn{2}{|c|}{ Mal (+) } & \multicolumn{2}{|c|}{ Mal (-) } & & \\
\hline & $\mathrm{n}$ & $\%$ & $\mathrm{n}$ & $\%$ & & \\
\hline$<1 \mathrm{x} / \mathrm{b} \ln$ & 17 & 27 & 11 & 17.5 & 95 & $0.375^{\#}$ \\
\hline $1-2 x / b l n$ & 43 & 68.3 & 47 & 74.6 & & \\
\hline \multirow[t]{2}{*}{$>2 \mathrm{x} / \mathrm{bln}$} & 3 & 4.8 & 5 & 7.9 & & \\
\hline & 63 & 100 & 63 & 10 & & \\
\hline
\end{tabular}

Keterangan : \# Uji Pearson Chi- Square = tidak berbeda siknifikan

Tabel 8 menunjukkan bahwa responden aktif melakukan kunjungan ANC. Responden yang tidak rutin melakukan kunjungan ANC setiap bulannya $(<1 \mathrm{x} /$ bulan) yaitu sebanyak $17(27 \%)$ responden pada kelompok Mal(+) dan 11(17.5\%) responden pada kelompok Mal(-). Hasil analisis uji beda pada kedua kelompok menunjukkan tidak ada perbedaan yang signifikan ( $\mathrm{p}>0.05)$.

\section{Jarak Kehamilan (spasing)}

Tabel 10. Gambaran karakteristik responden berdasarkan jarak kehamilan

\begin{tabular}{|c|c|c|c|c|c|c|}
\hline \multirow{3}{*}{ Kategori } & \multicolumn{4}{|c|}{ Kelompok } & \multirow{3}{*}{ CI \% } & \multirow[t]{3}{*}{$\mathrm{P}$} \\
\hline & \multicolumn{2}{|c|}{ Mal (+) } & \multicolumn{2}{|c|}{ Mal (-) } & & \\
\hline & $\mathrm{n}$ & $\%$ & $\mathrm{n}$ & $\%$ & & \\
\hline$<24$ bln & 15 & 23.8 & 10 & 15.9 & 95 & $0.171^{\#}$ \\
\hline $24-60$ bln & 24 & 38.1 & 17 & 27 & & \\
\hline \multirow[t]{2}{*}{$>60$ bln } & 2 & 3.2 & 5 & 7.9 & & \\
\hline & 41 & 65.1 & 32 & 50.8 & & \\
\hline
\end{tabular}

Keterangan :

\# Uji Pearson Chi-Square = tidak berbeda siknifikan

Tabel 10 menunjukkan bahwa pada kelompok Mal(+) sebanyak $15(23.8 \%)$ responden dengan jarak kehamilan kurang dari 24 bulan dan 2(3.2\%) lebih dari 60 bulan, sedangkan pada kelompok Mal(-) terdapat 10(15.9\%) responden dengan jarak kehamilan kurang dari 24 bulan dan 5(7.9\%) lebih dari 60 bulan. Hasil analisis uji beda pada kedua kelompok menunjukkan tidak ada perbedaan yang signifikan ( $p>0.05)$.

\section{Status Gizi}

Tabel 11. Gambaran status gizi responden berdasarkan LLA dan IMT

Variabel Kelompok CI \%

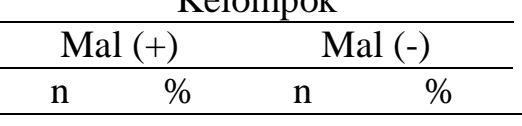

\section{Lingkar Lengan Atas}

(LLA)

$\operatorname{KEK}(<23.5 \mathrm{~cm})$

$\begin{array}{cccccc}6 & 9.5 & 6 & 9.5 & 95 & 1.000^{\#} \\ 57 & 90.5 & 57 & 90.5 & & \end{array}$

Tidak KEK $(\geq 23.5 \mathrm{~cm})$ 


\begin{tabular}{lcccccc}
\hline Indeks Massa Tubuh & 5 & 7.9 & 9 & 14.3 & 95 & $0.245^{\#}$ \\
(IMT) & 50 & 79.4 & 42 & 66.7 & & \\
Underweight & 7 & 11.1 & 12 & 19.0 & & \\
Normal & 1 & 1.6 & - & - & & \\
Overweight & & & & & & \\
Obese & & & & & \\
\hline
\end{tabular}

Keterangan : \# Uji Pearson Chi Square = tidak berbeda siknifikan

Tabel 11 menunjukkan bahwa berdasarkan pengukuran LLA pada kedua kelompok sebagian besar responden mempunyai status tidak KEK sebanyak $57(90.5 \%)$ responden. Berdasarkan IMT, normalweight sebanyak 50(79.4\%) responden pada kelompok $\operatorname{Mal}(+)$ dan $42(66.7 \%)$ responden pada kelompok Mal(-). Hasil analisis uji beda pada kedua kelompok menunjukkan tidak ada perbedaan yang signifikan $(\mathrm{p}>0.05)$.

Tingkat asupan energi, protein,Fe, asam folat, vitamin A dan vitamin $\mathrm{A}$

Tabel 12. Gambaran karakteristik tingkat asupan zat gizi responden

\begin{tabular}{|c|c|c|c|c|c|c|}
\hline \multirow[t]{3}{*}{ Kategori } & \multicolumn{4}{|c|}{ Kelompok } & \multirow[t]{3}{*}{ CI \% } & \multirow[t]{3}{*}{$\mathrm{P}$} \\
\hline & \multicolumn{2}{|c|}{ Kasus } & \multicolumn{2}{|c|}{ Kontrol } & & \\
\hline & $\mathrm{n}$ & $\%$ & $\mathrm{n}$ & $\%$ & & \\
\hline \multicolumn{7}{|l|}{ Energi } \\
\hline Defisit berat & 32 & 50.8 & 33 & 52.4 & 95 & $0.428^{\#}$ \\
\hline Defisit sedang & 14 & 22.2 & 11 & 17.5 & & \\
\hline Defisit ringan & 4 & 6.3 & 7 & 11.1 & & \\
\hline Cukup & 13 & 20.6 & 12 & 19.0 & & \\
\hline \multicolumn{7}{|l|}{ Protein } \\
\hline Defisit berat & 9 & 14.3 & 3 & 4.8 & 95 & $0.106^{\#}$ \\
\hline Defisit sedang & 10 & 15.9 & 6 & 9.5 & & \\
\hline Defisit ringan & 7 & 11.1 & 9 & 14.3 & & \\
\hline Cukup & 19 & 30.2 & 31 & 49.2 & & \\
\hline Lebih & 18 & 28.6 & 14 & 22.2 & & \\
\hline \multicolumn{7}{|l|}{$\mathbf{F e}$} \\
\hline Defisit berat & 57 & 90.5 & 60 & 95.2 & 95 & $0.598^{\#}$ \\
\hline Defisit sedang & 4 & 6.3 & 1 & 1.6 & & \\
\hline Defisit ringan & 1 & 1.6 & 1 & 1.6 & & \\
\hline Cukup & 1 & 1.6 & 1 & 1.6 & & \\
\hline \multicolumn{7}{|l|}{ Asam Folat } \\
\hline Defisit berat & 41 & 65.2 & 43 & 68.3 & 95 & $0.794^{\#}$ \\
\hline Defisit sedang & 12 & 19.0 & 10 & 15.9 & & \\
\hline Defisit ringan & 4 & 6.3 & 6 & 9.5 & & \\
\hline Cukup & 6 & 9.5 & 4 & 6.3 & & \\
\hline \multicolumn{7}{|l|}{ Vitamin A } \\
\hline Defisit Ringan & - & - & 1 & 1.6 & 95 & $0.215^{\#}$ \\
\hline Cukup & - & - & 2 & 3.2 & & \\
\hline Lebih & 63 & 100 & 60 & 95.2 & & \\
\hline \multicolumn{7}{|l|}{ Vitamin C } \\
\hline Defisit berat & 3 & 4.8 & 1 & 1.6 & 95 & $0.106^{\#}$ \\
\hline Defisit sedang & 1 & 1.6 & - & - & & \\
\hline Defisit ringan & 2 & 3.2 & 1 & 1.6 & & \\
\hline Cukup & 2 & 3.2 & 6 & 9.5 & & \\
\hline Lebih & 55 & 87.3 & 55 & 87.3 & & \\
\hline
\end{tabular}

Keterangan :n\# Uji Pearson Chi Square = tidak berbeda siknifikan 
Tabel 12 menunjukkan bahwa asupan makanan akan zat gizi rata-rata defisit. Pada kelompok $\mathrm{Mal}(+)$ asupan energi cukup hanya 13(20.6\%) responden, asupan protein cukup dan lebih masingmasing 19(30.2\%) dan 18(28.6\%) responden, asupan Fe cukup 1(1.6\%) responden, asupan asam folat cukup 6(9.5\%) reponden, asupan vitamin $\mathrm{A}$ semua responden dengan kategori lebih dan asupan vitamin $\mathrm{C}$ rata-rata lebih yaitu sebanyak 55 $(87.3 \%)$ responden. Pada kelompok Mal(-)asupan energi cukup sebanyak 12(19\%) responden, asupan cukup protein dan lebih masing-masing sebanyak 31(49.2\%) dan 14(22.2\%) responden, asupan cukup $\mathrm{Fe}$ hanya sebanyak 1(1.6\%) responden, asupan cukup asam folat sebanyak 4(6.3\%) responden, asupan vitamin A rata-rata lebih yaitu sebanyak 60(95.2\%) responden dan asupan vitamin C juga rata-rata lebih yaitu sebanyak 55(87.3\%) responden. Hasil analisis uji beda pada kedua kelompok menunjukkan tidak ada perbedaan yang signifikan ( $\mathrm{p}>0.05)$.

Suplementasi $\mathrm{Fe}^{+}$Asam Folat

Tabel 13. Konsumsi Tablet Fe Asam Folat

\begin{tabular}{|c|c|c|c|c|c|c|}
\hline \multirow{3}{*}{ Kategori } & \multicolumn{4}{|c|}{ Kelompok } & \multirow{3}{*}{ CI \% } & \multirow[t]{3}{*}{$\mathrm{P}$} \\
\hline & \multicolumn{2}{|c|}{ Mal (+) } & \multicolumn{2}{|c|}{ Mal (-) } & & \\
\hline & $\mathrm{n}$ & $\%$ & $\mathrm{n}$ & $\%$ & & \\
\hline$<30 \mathrm{tab} / \mathrm{bulan}$ & 1 & 1.6 & 1 & 1.6 & 95 & $0.129^{\#}$ \\
\hline$\geq 30 \mathrm{tab} / \mathrm{bulan}$ & 62 & 98.4 & 62 & 98.4 & & \\
\hline & 63 & 100 & 63 & 100 & & \\
\hline
\end{tabular}

Keterangan : \# Pearson Chi-Square Test = tidak berbeda siknifikan

Tabel 13 menunjukkan bahwa pada kedua kelompok terdapat masing-masing satu responden yang tidak rutin $(<30$ tablet/bulan) mengkonsumsi suplementasi $\mathrm{Fe}^{+}$Asam folat yang diberikan oleh bidan. Hasil analisis uji beda pada kedua kelompok menunjukkan tidak ada perbedaan yang signifikan $(\mathrm{p}>0.05)$.

\section{Parasitemia Malaria}

Pada kelompok kasus (Mal (+)) diketahui adanya infeksi Plasmodium Vivak sebesar 38
(60.3\%), infeksi Plasmodium Falcifarum 23 (36.5\%) dan infeksi oleh kedua Plasmodium Vivak dan Plasmodium Falcifarum sebanyak 2 (3.2\%). Sedangkan pada kelompok kontrol (Mal (-)) diambil yang bukan terinfeksi malaria yaitu hasil pemeriksaan malaria negatif adanya infeksi plasmodium. Pemberian terapi malaria diberikan pada kedua kelompok dengan distribusi dapat dilihat pada tabel 14 .

Tabel 14. Obat antimalaria

\begin{tabular}{|c|c|c|c|c|c|c|}
\hline \multirow{3}{*}{ Kategori } & \multicolumn{4}{|c|}{ Kelompok } & \multirow[t]{3}{*}{ CI \% } & \multirow[t]{3}{*}{$\mathrm{P}$} \\
\hline & \multicolumn{2}{|c|}{ Mal (+) } & \multicolumn{2}{|c|}{ Mal (-) } & & \\
\hline & $\mathrm{n}$ & $\%$ & $\mathrm{n}$ & $\%$ & & \\
\hline Quinine & 9 & 14.3 & 3 & 4.8 & 95 & $0.05^{\#}$ \\
\hline Kloroquin & 15 & 23.8 & 7 & 11.1 & & \\
\hline ACT & 14 & 22.2 & - & - & & \\
\hline \multirow[t]{2}{*}{ Unteraphy } & 25 & 39.7 & 53 & 84.1 & & \\
\hline & 63 & 100 & 63 & 100 & & \\
\hline
\end{tabular}

Keterangan : \# Uji Pearson Chi-Square = beda siknifikan

\section{Pemeriksaan Kadar Hb}

Tabel 15. Kategori Kadar $\mathrm{Hb}$

\begin{tabular}{|c|c|c|c|c|c|c|c|c|c|c|c|c|}
\hline \multirow[t]{3}{*}{ Kategori } & \multicolumn{4}{|c|}{$\mathrm{Hb} 1$} & \multirow{3}{*}{$\begin{array}{l}\mathrm{C} \\
\mathrm{I} \\
\%\end{array}$} & \multirow[t]{3}{*}{$\mathrm{p}$} & \multicolumn{4}{|c|}{$\mathrm{Hb} 2$} & \multirow{3}{*}{$\begin{array}{l}\text { CI } \\
\%\end{array}$} & \multirow[t]{3}{*}{$\mathrm{p}$} \\
\hline & \multicolumn{2}{|c|}{$\operatorname{Mal}(+)$} & \multicolumn{2}{|c|}{$\operatorname{Mal}(-)$} & & & \multicolumn{2}{|c|}{$\operatorname{Mal}(+)$} & \multicolumn{2}{|c|}{$\operatorname{Mal}(-)$} & & \\
\hline & $\mathrm{n}$ & $\%$ & $\mathrm{n}$ & $\%$ & & & $\mathrm{n}$ & $\%$ & $\mathrm{n}$ & $\%$ & & \\
\hline Kurang & 5 & 82. & 3 & 60. & 9 & 0.00 & 4 & 66. & 19 & 30.2 & 95 & 0.000 \\
\hline Cukup & 2 & 5 & 8 & 3 & 5 & 6 & 2 & 7 & 44 & 69.8 & & \\
\hline & 1 & 17. & 2 & 39. & & & 2 & 33. & & & & \\
\hline
\end{tabular}




\begin{tabular}{lllllllll}
\hline & 1 & 5 & 5 & 7 & 1 & 3 & & \\
\hline Jumlah & 6 & 100 & 6 & 100 & 6 & 100 & 63 & 100 \\
& 3 & & 3 & & 3 & & & \\
\hline
\end{tabular}

Keterangan : *Uji Pearson Chi-Square $=$ beda siknifikan

Tabel 15 menunjukkan bahwa kadar $\mathrm{Hb}$ awal (Hb1) dan $\mathrm{Hb}$ setelah suplementasi (Hb2) pada kedua kelompok persentase tertinggi yaitu kurang $(<11 \mathrm{gr} / \mathrm{dl})$. Pada kelompok $\mathrm{Mal}(+) \mathrm{Hb} 1$ dengan kategori kurang sebanyak 52(82.5\%) responden dan $38(60.3 \%)$ responden dengan $\mathrm{Hb} 2$ kurang dari $11 \mathrm{gr} / \mathrm{dl}$, sedangkan pada kelompok Mal(-) sebanyak $42(66.7 \%)$ responden dengan $\mathrm{Hb} 1$ kurang dari $11 \mathrm{gr} / \mathrm{dl}$ dan terjadi perubahan persentase pada Hb2 sebanyak 44(69.8\%) responden mempunyai kadar $\mathrm{Hb} \geq 11$ grl. Hasil analisis uji beda antar kelompok dan uji beda pada kedua kelompok menunjukkan ada perbedaan yang signifikan ( $\mathrm{p}<0.05)$.

\section{Rerata Kadar $\mathbf{H b}$}

Tabel 16. Rerata Kadar $\mathrm{Hb}$

\begin{tabular}{ccccc}
\hline \multirow{2}{*}{ Kelompok } & \multicolumn{2}{c}{ Hb } & \multirow{2}{*}{ CI } & $\mathrm{p}$ \\
\cline { 2 - 3 } & Awal & Akhir & $\%$ & \\
\hline Mal (+) & $10,03 \pm 1,511$ & $10,30 \pm 1,239$ & 95 & $0,00^{\epsilon}$ \\
Mal (-) & $10,57 \pm 1,604$ & $11,46 \pm 1,483$ & & $0,00^{\epsilon}$ \\
\hline $\mathrm{p}$ & $0,05^{*}$ & $0,00^{*}$ & \\
\hline
\end{tabular}

Keterangan :

* Uji Mann Whitney = beda siknifikan

$€$ Uji Wilcoxon Sign Rank = beda siknifikan

Tabel 16 menunjukkan bahwa rerata kadar $\mathrm{Hb}$ kurang dari $11 \mathrm{gr} / \mathrm{dl}$, kecuali pada $\mathrm{Hb} 2$ kelompok Mal(-) rerata kadar Hb sebesar 11.46gr/dl dengan SD 1.483. Hasil analisis uji beda antar kelompok berpasangan dan uji beda tidak berpasangan didapatkan ada perbedaan yang siknifikan $(\mathrm{p}<0.05)$

\section{Perubahan Kadar $\mathbf{H b}$}

Tabel 17. Perubahan Kadar $\mathrm{Hb}$

\begin{tabular}{ccccc}
\hline Kelompok & $\mathrm{n}$ & Mean $\pm \mathrm{SD}$ & $\mathrm{CI} \%$ & $\mathrm{P}$ \\
\hline $\operatorname{Mal}(+)$ & 63 & $0,270 \pm 0,615$ & & \\
$\operatorname{Mal}(-) 1$ & 63 & $0,886 \pm 0,749$ & & $0,000^{*}$ \\
\hline
\end{tabular}

Keterangan : * Mann Whitney Test $=$ beda siknifikan

Tabel 17 menunjukkan bahwa hasil analisis statistik terdapat perbedaan rerata kenaikkan kadar $\mathrm{Hb}$ pada kedua kelompok. Kenaikkan kadar $\mathrm{Hb}$ pada kelompok Mal(+) lebih kecil dari kelompok Mal(-), yaitu hanya sebesar $0.270 \mathrm{gr} / \mathrm{dl}$.

\section{PEMBAHASAN}

\section{Karakteristik Responden}

Kadar $\mathrm{Hb}$ pada ibu hamil dipengaruhi oleh beberapa faktor, antaralain ; umur responden, tingkat pendidikan, pekerjaan, suku budaya, tingkat pendapatan keluarga, tingkat pengetahuan gizi, paritas, umur kehamilan, frekwensi ANC, jarak kehamilan, status gizi dan asupan zat gizi (Energi, Protein, Fe, Asam Folat, Vitamin A dan Vitamin C. ${ }^{29,35}$

Umur ibu pada saat hamil akan mempengaruhi timbulnya anemia. Bila umur ibu pada saat hamil relatif muda $(<20$ tahun) akan beresiko anemia. Hal hal ini disebabkan karena pada umur $<20$ tahun masih terjadi pertumbuhan yang membutuhkan zat gizi lebih banyak dibandingkan dengan umur $>20$ tahun. Bila zat gizi yang dibutuhkan oleh ibu hamil tidak terpenuhi, maka akan terjadi kompetisi zat gizi antara ibu dengan bayinya. Semakin tinggi paritas 
maka resiko mengalami kekurangan $\mathrm{Hb}$ semakin tinggi. ${ }^{29,35}$

Tingkat pengetahuan berpengaruh terhadap perilaku dalam memilih makanan dan konsumsi suplementasi $\mathrm{Fe}^{+}$Asam Folat. Dengan adanya pengetahuan gizi terkait anemia dan zat besi, ibu hamil akan tahu pentingnya zat gizi dan bagaimana cara suplementasi $\mathrm{Fe}^{+}$Asam Folat. Tingkat pengetahuan dipengaruhi oleh tingkat pendidikan seseorang. Tingkat pendidikan juga mempengaruhi tingkat pendapatan keluarga dan asupan zat gizi seseorang. Semakin tinggi tingkat pendidikan seseorang semakin tinggi pula peluang untuk mendapatkan pekerjaan yang lebih baik. Tingkat pendapatan keluarga mempengaruhi pemilihan bahan makanan yang akan dikonsumsi. Resiko terjadinya defisiensi zat besi lebih besar pada keluarga dengan tingkat ekonomi rendah. Pada penelitian ini tingkat asupan ibu hamil akan energi, protein, Fe dan asam folat rata-rata masih kurang, sehingga perlu adanya program suplementasi yang lebih baik. Asupan makanan antaralain dipengaruhi oleh sosial budaya, dimana latar belakang budaya mempengaruhi pemilihan bahan makanan. ${ }^{29,38}$

Frekwensi kunjungan ANC juga mempengaruhi ibu hamil mendapatkan informasi tentang kesehatan termasuk suplementasi $\mathrm{Fe}^{+}$ Asam Folat dan Malaria. Semakin sering ibu melakukan kunjungan ANC semakin dini dan intensif deteksi resiko pada kehamilan yang disebabkan oleh defisiensi $\mathrm{Fe}^{+}$Asam Folat dan Malaria. Tingginya keaktifan ibu melakukan kunjungan ANC pada penelitian ini yaitu bahwa di daerah ini pelayanan kesehatan dianggap sesuatu yang sangat berharga, tingginya kepercayaan masyarakat terhadap tenaga kesehatan dan fasilitas kesehatan yang masih terjangkau. ${ }^{40}$

Pada penelitian ini faktor-faktor tersebut dapat dikendalikan dengan cara matching sehingga pada kedua kelompok tidak terdapat perbedaan distribusi yang siknifikan.

\section{Suplementasi $\mathrm{Fe}^{+}$Asam Folat}

Suplementasi $\mathrm{Fe}^{+}$Asam Folat pada penelitian ini $98.4 \%$ responden pada setiap kelompok mengkonsumsi satu tablet perhari atau $\geq$ 30 tablet per 30 hari. Dengan demikian tingkat kepatuhan suplementasi $\mathrm{Fe}^{+}$Asam Folat adalah tinggi. Kepatuhan ibu hamil dalam mengkonsumsi tablet $\mathrm{Fe}^{+}$Asam Folat dipengaruhi oleh tingkat pengetahuan ibu tentang anemia dan zat besi. Semakin tinggi tingkat pengetahuan seseorang maka akan semakin mudah menerima informasi yang positif dan akan bermanifestasi terhadap perubahan perilaku tentang suplementasi $\mathrm{Fe}^{+}$Asam
Folat. Kepatuhan ibu hamil juga dipengaruhi oleh tingkat kepercayaan ibu terhadap tenaga kesehatan dalam hal ini bidan dan tenaga gizi yang terlibat dalam pemeriksaan kehamilan ibu di Puskesmas. ${ }^{40,41}$

Hasil penelitian terdahulu yang dilakukan pada wanita hamil di Ghana menunjukan bahwa dengan suplementasi $\mathrm{Fe}^{+}$dan Zink dapat meningkatkan kadar $\mathrm{Hb}$ sebesar 0.6 gr/dl. Penelitian Oleh Taru Argawal di India memberikan informasi bahwa pada ibu hamil yang mendapatkan suplementasi tablet $\mathrm{Fe}^{+}$mempunyai kadar $\mathrm{Hb}$ yang lebih tinggi dari kelompok dengan pemberian makan tinggi besi dan kelompok kontrol. Pada penelitian ini diketahui bahwa pada responden yang mengkonsumsi tablet $\mathrm{Fe}^{+}$Asam Folat $\geq 30$ mengalami perubahan kadar $\mathrm{Hb} 3.13$ kali lebih besar dibandingkan yang mengkonsumsi $<30$ tablet. Pemberian suplementasi $\mathrm{Fe}^{+}$yang tepat pada setiap ibu hamil akan memberikan pengaruh positif terhadap keberhasilan program suplementasi $\mathrm{Fe}^{+}$Asam Folat untuk meningkatkan kadar Hb pada ibu hamil. ${ }^{36,37}$

\section{Perubahan Kadar $\mathbf{H b}$}

Pada ibu hamil yang terinfeksi malaria kadar $\mathrm{Hb}$ lebih rendah dari ibu hamil yang tidak terinfeksi malaria. Malaria berkontribusi terhadap kejadian anemia pada ibu hamil. Penelitian tentang Hubungan Plasmodium Falcifarum dengan anemia pada ibu hamil oleh Guyatt dan Snow yang dilakukan didaerah sub Sahara Africa menunjukan bahwa setiap tahun sekitar 400 ribu wanita hamil yang terinfeksi malaria mempunyai kadar $\mathrm{Hb}<8$ $\mathrm{gr} / \mathrm{dl}{ }^{30,18}$

Hasil penelitian ini terdapat perubahan kadar $\mathrm{Hb}$ pada ibu hamil terinfeksi malaria lebih kecil dibandingkan perubahan kadar $\mathrm{Hb}$ pada ibu hamil yang tidak terinfeksi malaria. Hal ini disebabkan karena perubahan kadar $\mathrm{Hb}$ pada ibu hamil yang terinfeksi malaria dihambat oleh adanya infeksi parasit plasmodium dan adanya terapi antimalaria. Parasit malaria menginfestasi eritrosit yang menyebabkan penghambatan eritropoesis dan fagositosis eritrosit baik yang mengandung dan tidak mengandung parasit. Selain itu penghambatan perubahan $\mathrm{Hb}$ pada ibu yang mengkonsumsi antimalaria dapat terjadi melalui mekanisme efek samping dari antimalaria yang terutama mengakibatkan gangguan fungsi gastrointestinal, mual, muntah, diare dan gangguan syaraf yang akan berdampak mengganggu asupan dan absorbsi zat gizi yang dibutuhkan oleh ibu hamil terutama besi dan asam folat. ${ }^{32,34,39}$ 


\section{KETERBATASAN PENELITIAN}

Secara teknis jauhnya lokasi penelitian dan keterbatasan sarana dan fasilitas kesehatan sehingga penelitian ini tidak bisa menggali data yang laboratorium terkait $\mathrm{Hb}$ secara lebih spesifik dan faktor-faktor lain yang mempengaruhi kadar $\mathrm{Hb}$ pada ibu hamil dengan infeksi malaria.

\section{SIMPULAN}

Dengan karakteristik kedua kelompok yang tidak berbeda diperoleh bahwa terdapat perbedaan perubahan kadar $\mathrm{Hb}$ pada ibu hamil yang terinfeksi malaria dan yang tidak terinfeksi malaria yang mendapatkan suplementasi $\mathrm{Fe}^{+}$Asam Folat. Perubahan kadar $\mathrm{Hb}$ pada ibu hamil yang terinfeksi malaria dihambat oleh parasit Plasmodium dan efek samping dari terapi antimalaria. Pemberian suplementasi $\mathrm{Fe}^{+}$Asam Folat pada ibu hamil terinfeksi malaria masih kurang efektif, oleh karena itu perlu dikaji bentuk program lainnya dalam rangka pengendalian anemia ibu hamil didaerah endemik.

\section{SARAN}

Perlu dilakukan penelitian dan pengkajian lebih lanjut terkait suplementasi Fe dan faktor yang mempengaruhi terjadinya anemia pada ibu hamil terinfeksi malaria, agar program suplementasi $\mathrm{Fe}^{+}$ pada ibu hamil didaerah endemik malaria bisa mendapatkan hasil yang maksimal.

Perlu adanya program terpadu yang mencakup penanggulangan malaria, masalah gizi dan sanitasi lingkungan pada ibu hamil, sehingga masalah malaria dan masalah gizi pada ibu hamil didaerah endemik dapat dikendalikan.

\section{UCAPAN TERIMAKASIH}

Puji syukur saya ucapkan kepada Allah SWT atas limpahan rahmat dan karuniaNya. Terima kasih saya ucapkan kepada Prof.dr HM. Sulchan, MSc.,DA.Nutr.,SpGK, selaku pembimbing dan para reviewer yang telah membimbing penelitian ini sehingga dapat diselesaikan. Ucapan terima kasih juga saya ucapkan kepada suami, putera dan teman-teman yang telah membantu dan memberi dukungan selama proses penelitian ini berlangsung.

\section{DAFTAR PUSTAKA}

1. World Health Organitation. Global Nutrition Policy Review : What Does It Take To Scale Up Nutrition Action?. Geneva, 2013
2. Kerangka kebijakan gerakan sadar gizi dalam rangka seribu hari pertama kehidupan Pemerintah Republik Indonesia. Jakarta, 2012. Hal : 17

3. WHO Global Database on Anaemia. Anaemia as a public health problem by country : Pregnant women. World Health Organization. Geneva, 2008

4. Kementrian Kesehatan RI. Epidemiologi Malaria Di Indonesia, Buletin Jendela dan data Informasi Kesehatan, Vol 1 Triwulan 1 2011. Jakarta, 2011

5. Dinas Kesehatan Kabupaten Nabire. Laporan Malaria Tahun 2012 . Seksi Pemberantasan Penyakit Menular . Nabire, 2012

6. Price Sylvia Anderson. Patofisiologi : Konsep Klinis Proses-Proses Penyakit/Sylvia Anderson Price, Lorraine McCarty Wilson; alih bahasa, Brahm U. Pendit....[et.al.] ; editor edisi bahasa Indonesia, Huriawati Hartanto.... [et. Al.]. -Ed.6- . EGC. Jakarta, 2005

7. World Health Organization Global Malaria Programme. Malaria : Global Fund Proposal Development (Round 11). WHO Policy Brief. Jull 2011

8. Pusat Data dan Informasi Kementerian Kesehatan Republik Indonesia. Data/Informasi Kesehatan Propinsi Papua 2011. Kementerian Kesehatan Republik Indonesia. Jakarta, 2013.

9. Pavord S. UK guidelines on the management of iron deficiency in pregnancy. British Committee for Standards in Haematology. London, Jully 2011.

10. Supriasa, I Dewa Nyoman. Penilaian Status Gizi / I Dewa Nyoman Supriasa, Ibnu Fajar, Bachyar Bakri. EGC. Jakarta, 2001

11. Sopiyudin Dahlan M. Statistik Untuk Kedokteran dan Kesehatan : Deskriptif, Bivariat, Multivariat Dilengakapi Aplikasi dengan Menggunakan SPSS.Salemba Medika. Jakarta, 2008

12. Pusat Promosi Kesehatan. Rencana Operasional Promosi Kesehatan Ibu dan Anak. Kementerian Kesehatan Republik Indonesia . Jakarta, 2010.

13. Pemerintah Kabupaten Nabire. Kabupaten Nabire Dalam Angka. Badan Pusat Statistik Kabupaten Nabire, Nabire, 2011

14. Badan Penelitian Dan Pengembangan Kesehatan. Riset Kesehatan Dasar 2010, Kementerian Kesehatan Republik Indonesia. Jakarta, 2010

15. Pusat Data Dan Informasi. Ringkasan Eksekutif Profil Kesehatan Propinsi Papua. Kementerian Kesehatan Republik Indonesia. Jakarta , 2011

16. John W Feightner. Routine Iron Suplementation During Pregnancy.

17. Steketee W Richard, dkk. The Burden Of Malaria In Pregnancy In Malaria-Endemic Areas. The American Society of Tropical Medicine and Hygiene. 64(1, 2)S, 2001, pp. 28-3

18. Steketee W Richard. Infection And Inflamation : Pregnancy, Nutritionand Parasitic Diseases, Division of Parasitic Diseases, National Center for Infectious Diseases, Centers for Disease Control 
and Prevention, Atlanta, The Journal Of Nutrition, Downloaded from jn.nutrition.org by guest on January 23, 2013

19. Ansar, dkk. Faktor-Faktor Yang Berkaitan Dengan Kejadian Anemia Di Daerah Endemik Malaria Kabupaten Mamuju Propinsi Sulawesi Barat, Indonesia,Universitas Hasanuddin, Makassar. JST Kesehatan, Januari 2012, Vol.2 No.1 : 18 - 26

20. Pearce Evelyn. Anatomi dan Fisiologi untuk paramedis, alih bahasa ; Sri Yuliani Handoyo. Gramedia Pustaka Utama. Jakarta, 2006

21. Sudigdo Sastroasmoro. Dasar-Dasar Metodologi Penelititan Klinis edisi 3. CV. Sagung Seto.Jakarta, 2008

22. Widyakarya Nasional Pangan Dan Gizi X. Penyempurnaan Kecukupan Gizi Untuk Orang Indonesia , 2012. Pokja AKG ; Djoko Kartono et.al. Jakarta, 2012

23. Sibagariang Eva Ellya. Gizi Dalam Kesehatan Reproduksi. TIM. Jakarta, 2010

24. Bilimale Anil, et al. Improving Adherence to Oral Iron Suplementation During Pregnancy. Ohio University. USA. Australian Medical Journal, 2010, 3,5, 281-290

25. Robert F Dons. Endocrine and Metabolic Disorders : Clinical Lab Testing Manual/ Robert F Dons and Frank H Wians Jr.-4th ed. CRC Press. Roca Baton. 2009

26. John L Beard. Effectiveness and Strategies of Iron Suplementation during Pregnancy. Am J Clin Nutr 2000;71(suppl):1288S-94S. Printed in USA. (C) 2000 American Society for Clinical Nutrition.

27. Sean Lynch. Indicator of The Iron Status of Populations : Red Blood Cell Parameters

28. Lynch Caroline and Sean Hewitt. Malaria in The Asia-Pasific : Burden, Succes and Challenges Paper 1, October 2010. Publication in : Malaria Saving Lives in The Asia-Pasific, 2012

29. Wara FT. Faktor-Faktor Yang Mempengaruhi Status Anemia Pada Ibu Hamil Di Kecamatan Ciampea, Kabupaten Bogor Jawa Barat. Institut Pertanian Bogor, 2006

30. Rosdiana Nelly, dkk. Gambaran Hematologis pada Anemia Akibat Infeksi Kronis di Daerah Endemis Malaria. Sari Pediatri, Vol 8, No.3 Suppl, Januari 2007 : 57-61.

31. Stalker Peter. Milenium Development Goal's. UNDP, Oktober 2008

32. Departemen Farmakologi dan Terapeutik Fakultas Kedokteran Universitas Indonesia. Farmakologi dan Terapi, Ed. 5. Balai Penerbit FKUI. Jakarta, 2008

33. Hoover KL. Handbook of Drug-Nutrient Interactions, Edited by Joseph I Boullata and Vincent T Armenti. Human Press. New Jersey, 2004

34. Oleksii A, et al. Inhibition of Erythropoiesis in Malaria Anemia : Hemozoin-Generated 4Hydroxinoneal. American Society of Hematology.
Published by Blood Journal Hematology. August 2010, 116 : 4328-4337.

35. Turena Indah Julianti. Gambaran Malaria Dalam Kehamilan Di RSUD Kabupaten Mimika Tahun 2010.

36. Taru Agarwal, et al. Impact of Iron Supplementation on Anemia During Pregnancy. Kurukshetra University. India. Publ at Ethno Med.., 2 (2) : 149-151 (2008).

37. Sloan Nancy L, Jordan Elizabeth and Winikoff Beverly. Effect of Iron Suplementation on Maternal Hematologic Status in Pregnancy. American Journal of Public Health. February 2002, vol 92, No.2.

38. Shezadi Sabah, Irum Fatima,and Ramzan Musarat. Iron Deficiency Anemia ; Role of Nutritional Deprivation Among Female Patients of Reproductive Age Group. Profesional Medical Journal. December 2010, 17 (4). 686-690.

39. World Health Organization. Guidelines For The Treatment of Malaria-2nd edition. World Health Organization Press. Geneva 2010 .

40. Soekidjo Notoatmodjo. Pendidikan dan Perilaku Kesehatan. Rineka Cipta. Jakarta. 2003.

41. Mardhatillah Fuady, Datten Bangun. Hubungan Kepatuhan Ibu Hamil tentang Anemia Defisiensi Besi terhadap Kepatuhan Mengkonsumsi Tablet Zat Besi. E-Journal FK USU, Vol 1 No 1, Februari 2013. 